\title{
Respon Perokok Remaja Terhadap Peringatan Kesehatan Bergambar di Bungkus Rokok
}

\section{Teenage Smokers' Responses to Pictorial Health Warning on Cigarratte Pack}

\author{
Leni Nurahmi, Rita Damayanti \\ Departemen Pendidikan Kesehatan dan Ilmu Perilaku, Fakultas Kesehatan Masyarakat Universitas Indonesia
}

\begin{abstract}
ABSTRAK
Latar Belakang. Merokok masih menjadi faktor risiko penyakit kronis dan mematikan di dunia. Tahun 2014 terdapat 5,8 milyar perokok di dunia, 80 persennya mulai merokok saat remaja. Di Indonesia pun rata-rata usia pertama kali merokok sekitar 17,6 tahun. Untuk melindungi remaja dari bahaya merokok, peringatan kesehatan bergambar (PKB) dengan kesan menakutkan telah dicantumkan pada bungkus rokok. Per 24 Juni 2014, PKB telah berlaku di Indonesia.

Tujuan. Penelitian bertujuan untuk mengetahui gambaran respon perokok remaja di Kota Depok terhadap pesan dengan kesan menakutkan pada PKB di Indonesia.

Metode. Penelitian menggunakan desain cross sectional dengan kuesioner dari Pusat Penelitian Kesehatan Universitas Indonesia (PPK UI) sebagai instumen penelitian.

Hasil. Penelitian menemukan perbedaan gambaran rasa takut, keparahan, respon efikasi serta perbedaan frekuensi niat. Namun, tidak ditemukan perbedaan gambaran kerentanan, efikasi diri, penerimaan serta penolakan pesan terhadap pesan dalam PKB.
\end{abstract}

Kata kunci: peringatan kesehatan bergambar, kesan menakutkan, perokok remaja.

\section{ABSTRACT}

Background. Smoking is risk factor of chronic and deadly diseases in the world. In 2014, 80\% of 5.8 billion smokers in the world started smoking at 17.6 years old. Pictorial health warning on cigarette pack was implemented since 24 June 2014 in Indonesia to protect teenagers from smoking.

Objective. This study aimed to assess teenage smokers' responses toward pictorial health warning on cigarette pack in Depok City.

Method. This cross-sectional study used a questionnaire from the Center for Health Research Universitas Indoonesia.

Result. We found differences in fear, severity, response efficacy and intention. We found no differences in susceptibility, self efficacy, acceptance and ignorance to pictorial health warning.

Keyword: pictorial health warning, fear appeal, teenage smoker. 


\section{LATAR BELAKANG}

Sampai saat ini, merokok masih menjadi faktor risiko bagi penyakit kronis dan mematikan di dunia. ${ }^{1}$ Data menunjukkan merokok menjadi penyebab 71 persen kanker paru, 42 persen penyakit pernapasan kronik serta 10 persen penyakit kardiovaskuler, di mana ketiga penyakit ini adalah penyakit-penyakit mematikan di dunia. ${ }^{2}$ Hampir enam juta orang meninggal per tahun akibat merokok, atau 10 persen dari kematian di dunia disebabkan karena penyakit yang berkaitan dengan kebiasaan merokok, dan diperkirakan pada tahun 2020, jumlah tersebut akan meningkat menjadi 7,5 juta per tahun. ${ }^{3}$ Sampai tahun 2014 , terdapat 5,8 milyar perokok di dunia, ${ }^{3}$ dimana 80 persen dari seluruh perokok di dunia tersebut mulai merokok pada usia remaja. ${ }^{4}$

Laporan Riskesdas 2010 menunjukkan data bahwa rata-rata usia mulai merokok di Indonesia yaitu 17,6 tahun, penduduk Jawa Barat usia 10 tahun ke atas kebanyakan mulai merokok pertama kali setiap hari pada usia 12-20 tahun. ${ }^{5}$ Pada tahun 2012, Depok sebagai salah satu kota di Jawa Barat pun menunjukkan data bahwa sekitar 34,7 persen pelajar di Kota Depok adalah perokok. ${ }^{6}$ Dari data yang telah dipaparkan terlihat bahwa baik secara global, nasional, maupun regional terjadi pola perilaku merokok yang sama yaitu perokok di kalangan remaja menunjukkan prevalensi yang masih tinggi.

The Centers for Disease Control (CDC) mengatakan bahwa rendahnya akses terhadap pendidikan dan rendahnya status sosial ekonomi adalah faktor risiko bagi remaja untuk memulai merokok. ${ }^{7}$ Pusat Kegiatan Belajar Masyarakat (PKBM) merupakah fasilitas pendidikan non-formal yang disediakan oleh pemerintah Kota Depok sebagai upaya pemerataan dan perluasan akses pendidikan untuk semua warga Kota Depok. Berdasarkan temuan di lapangan ternyata peserta didik PKBM di Kota Depok sebagian besar berasal dari kalangan menengah ke bawah.

Untuk melindungi generasi sekarang dan generasi mendatang dari bahaya merokok, Organisasi Kesehatan Dunia (World Health Organization/ WHO) menyetujui kesepakatan kesehatan masyarakat internasional pertama mengenai pengendalian tembakau, yaitu Framework Convention on Tobacco Control (FCTC). Per 24 Juni 2014 lalu Indonesia pun telah resmi mewajibkan para produsen produk tembakau di Indonesia untuk mencantumkan peringatan kesehatan dalam bentuk gambar maupun tulisan pada setiap kemasan produknya. Peraturan yang menaungi pencantuman peringatan kesehatan bergambar pada bungkus rokok di Indonesia adalah UU Nomor 36 Tahun 2009 tentang Kesehatan, Peraturan Pemerintah Nomor 109 Tahun 2012 tentang Pengamanan Bahan yang Mengandung Zat Adiktif berupa Produk Tembakau bagi Kesehatan serta Peraturan Menteri Kesehatan Nomor 28 Tahun 2013 tentang Pencantuman Peringatan Kesehatan dan Informasi Kesehatan dalam Kemasan Produk Tembakau.

The Extended Parallel Process Model (EPPM) dari Kim Witte merupakan model yang dapat menganalisis kesuksesan maupun kegagalan kesan menakutkan seperti yang dipakai dalam peringatan bergambar pada bungkus rokok di Indonesia. ${ }^{8}$ Namun, belum banyak penelitian yang menggunakan konsep EPPM untuk melihat respon remaja di Indonesia terhadap kesan menakutkan dalam peringatan kesehatan bergambar. Oleh sebab itu, penelitian ini dilakukan untuk melihat gambaran respon remaja terhadap kesan menakutkan peringatan kesehatan bergambar pada bungkus rokok berdasarkan variablevariabel dalam EPPM.

\section{METODE}

Penelitian ini merupakan jenis penelitian kuantitatif yang menekankan pada pengumpulan data numerik atau data yang dapat dikuantifikasi dan dianalisis secara statistik. Metode penelitiaan yang digunakan adalah penelitian deskriptif yang bertujuan mendeskripsikan hasil dari suatu program. Desain penelitian yang digunakan adalah cross-sectional, di mana variabel independen maupun variabel dependen diamati pada waktu yang bersamaan. ${ }^{9}$ 
Tabel 1. Gambaran Karakteristik Perokok Remaja Peserta Didik PKBM di Kota Depok Tahun 2015

\begin{tabular}{|c|c|c|c|c|}
\hline Karakteristik Responden & $\mathbf{s}$ & $\%$ & Mean & $\begin{array}{r}\text { Standar } \\
\text { deviasi }\end{array}$ \\
\hline \multicolumn{5}{|l|}{ Usia responden (dalam tahun) } \\
\hline $13-14$ & 10 & 6,0 & & \\
\hline $15-16$ & 67 & 40.4 & & \\
\hline $17-18$ & 57 & 34,4 & 17 & 1,779 \\
\hline $19-20$ & 32 & 19,3 & & \\
\hline \multicolumn{5}{|l|}{ Jenis kelamin responden } \\
\hline Laki-laki & 152 & 91,6 & & \\
\hline Perempuan & 14 & 8.4 & & \\
\hline \multicolumn{5}{|l|}{$\begin{array}{l}\text { Usia pertama kali merokok (dalam } \\
\text { tahun) }\end{array}$} \\
\hline $5-9$ & 20 & 12.1 & 13 & 2.759 \\
\hline $10-14$ & 84 & 50,6 & & \\
\hline $15-19$ & 62 & 37.3 & & \\
\hline \multicolumn{5}{|c|}{ Riwayat merokok } \\
\hline \multicolumn{5}{|c|}{$\begin{array}{l}\text { Dalam sebulan terakhir, berapa kali anda } \\
\text { pernah merokok? }\end{array}$} \\
\hline 1. Satu kali & 18 & 10.8 & & \\
\hline 2. Lebuh dari satu kali & 148 & 89,2 & & \\
\hline \multicolumn{5}{|l|}{ Tingkat adiksi nikotin } \\
\hline Rendah $(0-2)$ & 113 & 68,1 & & \\
\hline Sedang $(3-4)$ & 50 & 30.1 & 2 & 1,404 \\
\hline Tinggi $(5-6)$ & 3 & 1,8 & & \\
\hline
\end{tabular}

Penelitian dilakukan pada bulan Maret hingga Mei 2015 bertempat di PKBM Kota Depok. Populasi penelitian ini adalah remaja usia 12-20 tahun, berstatus perokok, serta terdaftar sebagai peserta didik di PKBM Kota Depok. Jumlah sampel dalam penelitian ini adalah 166 orang yang diambil dengan metode accidental sampling.

Pengumpulan data dilakukan dengan metode self administred menggunakan kuesioner dari Pusat Penelitian Kesehatan Universitas Indonesia (PPK UI). Data yang telah terkumpul diolah dengan menggunakan perangkat lunak statistik dan dianalisis dengan dua metode yaitu analisis univariat dan analisis bivariat. Analisis data secara univariat dilakukan untuk melihat distribusi frekuensi masing-masing variabel EPPM sehingga terlihat pola karakteristik dan variasi dari tiap variabel. Analisis bivariat digunakan untuk membandingkan dua kelompok data. Uji yang digunakan dalam analisis bivariat adalah uji chi-square dan uji beda dua mean dependen (paired-sample $T$ test).

\section{HASIL}

Dari hasil analisis karakteristik perokok remaja peserta didik PKBM Kota Depok tahun 2015 (Tabel 1), diketahui ada 40,4\% (67 orang) responden berusia sekitar 15-16 tahun, hampir keseluruhan responden $(91,6 \%)$ adalah laki-laki, sebagian besar $(50,6 \%)$ responden mulai merokok pada usia sekitar 10-14 tahun, sebagian besar responden $(89,2 \%)$ mengaku lebih dari satu kali merokok dalam satu bulan terakhir, dan sebagian besar responden $(68,1 \%$ memiliki tingkat adiksi nikotin yang rendah.

Dalam hal rasa takut (Figur 1), sebagian besar responden menganggap bahwa gambar tengkorak (gambar 1) biasa saja $(42,1 \%$ dan $38,6 \%)$. Kemudian, sebagian besar responden (27,7\%) menganggap gambar kanker mulut (gambar 2) biasa saja, dan 49 responden $(29,5 \%)$ menganggap sangat menjijikan. 
Figur 1. Distribusi Perokok Remaja Peserta Didik PKBM di Kota Depok berdasarkan Rasa Takut terhadap PKB di Bungkus Rokok Tahun 2015

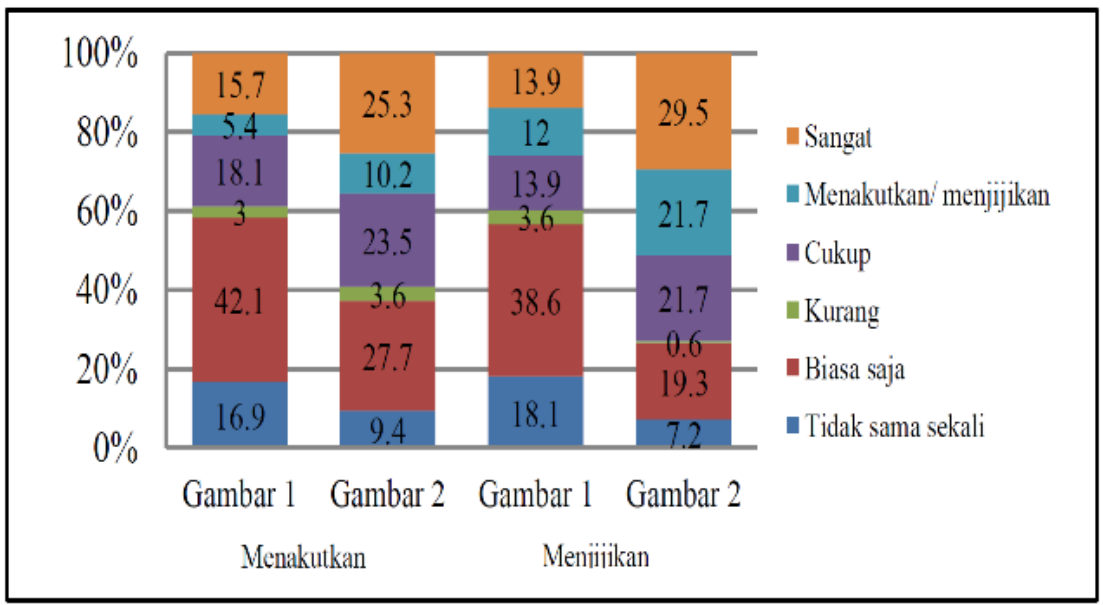

Dalam hal persepsi ancaman knususnya keparahan, sebagian besar responden memberikan respon biasa saja dan cukup berbahaya (masing-masing 25,9\%) tentang bahaya merokok bagi kehidupan mereka, sebagian besar responden memberikan respon sangat berbahaya $(36,1 \%)$ dan berbahaya $(23,5 \%)$ tentang bahaya kanker mulut bagi kehidupan mereka. Pada item kedua, sebagian besar responden merasa yakin $(29,5 \%)$ bahwa merokok dapat membahayakan kesehatan mereka. Selanjutnya, sebagian besar merasa yakin $(25,3 \%)$ bahwa penyakit kanker mulut dapat mengakibatkan kematian. Pada item ketiga (terakhir) dalam kategori keparahan, setelah melihat peringatan kesehatan bergambar (gambar tengkorak maupun kanker mulut), sebagian besar responden percaya $(24,7 \%)$ dan cukup percaya $(21,1 \%)$ bahwa merokok dapat mengakibatkan kematian. Kemudian, sebagian besar responden percaya $(27,1 \%)$ bahwa merokok dapat menyebabkan kanker mulut.

Dalam hal kerentanan, sebagian besar responden merasa cukup khawatir $(24,1 \%)$ terhadap kesehatan diri mereka. Setelah melihat gambar kanker mulut, sebagian besar responden merasa sangat khawatir $(25,3 \%)$ terhadap kesehatan diri mereka. Pada item kedua kerentanan, sebagian besar responden merasa percaya $(22,9 \%)$ bahwa suatu saat mereka bisa menınggal karena kebıasaan merokok dan merasa biasa saja $(24,1 \%)$ bahwa suatu saat mereka bisa terkena kanker mulut akibat merokok.

Dalam hal persepsi efikasi untuk dimenasi efikasi respon, respon cukup percaya $(19,9 \%)$ dan biasa saja $(19,3 \%)$ mengenai efektifitas mengurangi jumlah rokok yang dihisap dalam memperpanjang usia mereka adalah respon terbanyak yang dipilih oleh responden. Kemudian, mengenai efektifitas mengurangi jumlah rokok yang dihisap dalam pencegahan kanker mulut, responden terbanyak merasa sangat percaya $(22,3 \%)$ dan percaya $(20,5 \%)$ akan hal tersebut. Sama halnya pada item kedua untuk efikasi respon (gambar tengkorak), terjadi pola yang rata namun reponden paling banyak memberikan respon biasa saja $(21,1 \%)$, cukup percaya dan sangat percaya (masing-masing $18,1 \%$ ) bahwa berhenti merokok dapat memperpanjang usia mereka. Pola jawaban yang berbeda terjadi dalam respon efikasi dalam mencegah kanker mulut, 22,3\% reponden merasa sangat percaya dan $20,5 \%$ responden merasa percaya bahwa mengurangi jumlah rokok yang dihisap dapat mencegah kanker mulut. Kemudian, respon terhadap efektifitas berhenti merokok dalam mencegah kanker mulut, 43 responden $(25,9 \%)$ merasa sangat percaya dan 33 responden $(19,9 \%)$ merasa percaya akan hal tersebut. 
Figur 2. Distribusi Perokok Remaja Peserta Didik PKBM di Kota Depok berdasarkan Persepsi Ancaman terhadap PKB di Bungkus Rokok Tahun 2015

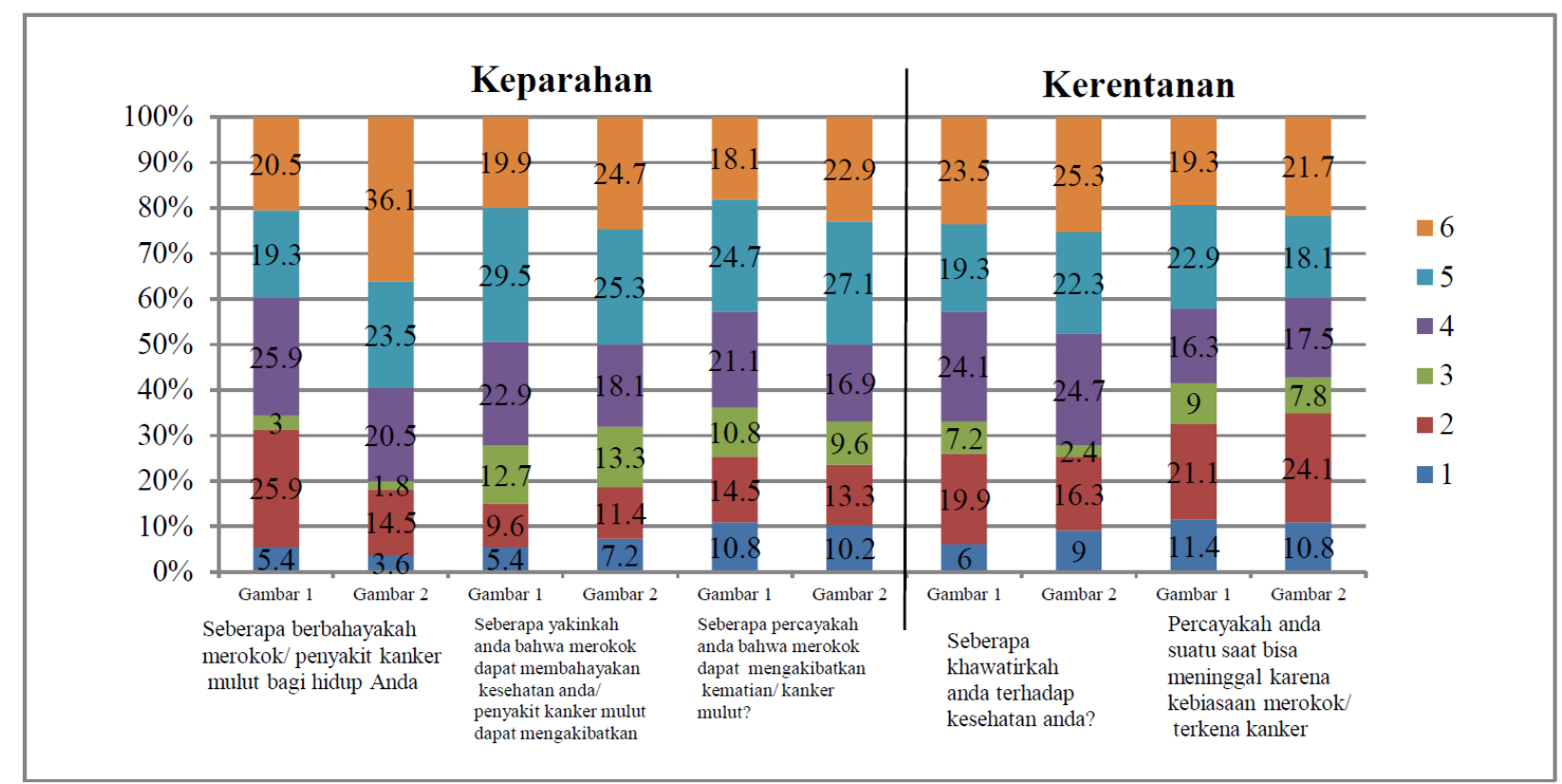

Figur 3. Distribusi Perokok Remaja Peserta Didik PKBM di Kota Depok berdasarkan Persepsi Efikasi terhadap PKB di Bungkus Rokok Tahun 2015

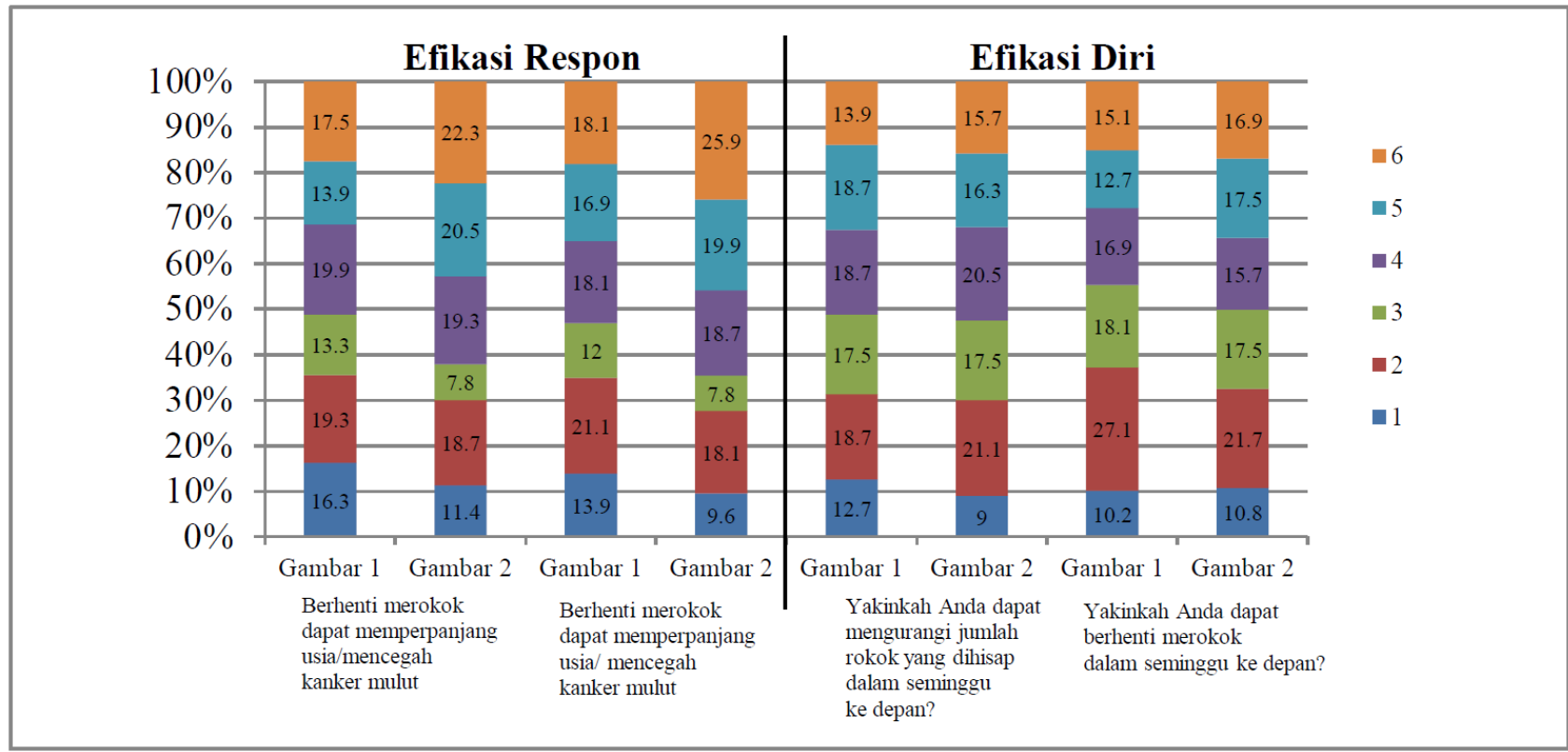

Dalam aspek efikasi diri, masing-masing 31 responden $(18,7 \%)$ merasa tidak yakin, cukup yakin, dan yakin mampu mengurangi jumlah rokok yang dihisap dalam seminggu ke depan untuk memperpanjang usia mereka, sebanyak 35 responden $(21,1 \%)$ merasa kurang yakin mampu mengurangi jumlah rokok yang dihisap dalam seminggu ke depan untuk mencegah dirinya terkena kanker mulut akibat merokok. Selain mengurangi jumlah rokok, respon yang direkomendasikan untuk memperpanjang usia dan mencegah kanker mulut akibat merokok adalah berhenti merokok. Sebanyak 45 responden $(27,1 \%)$ merasa tidak yakin mampu berhenti merokok dalam seminggu ke depan untuk memperpanjang usianya, 
sebanyak 36 responden $(21,7 \%)$ merasa tidak yakin mampu berhenti merokok dalam seminggu kedepan untuk mencegah dirinya terkena kanker mulut akibat merokok.

Kemudian, dalam respon penerimaan pesan untuk variabel sikap, didapatkan hasil baik pada gambar tengkorak maupun gambar kanker mulut terjadi pola jawaban yang hampir sama. Sebagian besar responden memberikan respon netral bahwa gambar tengkorak sesuai pandangan mereka akan bahaya merokok dan memotivasi untuk berhenti merokok (masing-masing $36,1 \%$ ), membuat remaja lebih perhatian akan bahaya merokok $(34,9 \%)$, mampu mencegah remaja memulai merokok $(29,5 \%)$. Kemudian, untuk gambar kanker mulut, sebagian besar memberikan respon netral bahwa sesuai pandangan mereka akan bahaya merokok $(28,9 \%)$, memotivasi untuk berhenti merokok $(36,1 \%)$, membuat remaja lebih perhatian akan bahaya merokok $(30,1 \%)$, mampu mencegah remaja memulai merokok (28,3\%).

Untuk perilaku batal merokok, hasil penelitian baik pada gambar tengkorak maupun kanker mulut menunjukkan pola jawaban yang sama. Sebagian besar responden $(41,6 \%)$ mengaku tidak pernah batal merokok karena melihat gambar tengkorak dan sebagian besar responden $(43,4 \%)$ mengaku tidak pernah batal merokok akibat melihat gambar kanker mulut pada bungkus rokok yang ia beli. Dalam hal niat, terdapat 72 responden $(43,4 \%)$ yang menyatakan bahwa PKB tengkorak, dan sebanyak 87 responden $(52,4 \%)$ menyatakan bahwa PKB kanker mulut membuatnya berniat untuk berhenti merokok dalam 6 bulan ke depan.

\section{Figur 4. Distribusi Perokok Remaja Peserta Didik PKBM di Kota Depok berdasarkan Respon Penerimaan Pesan (Sikap) terhadap PKB di Bungkus Rokok Tahun 2015}

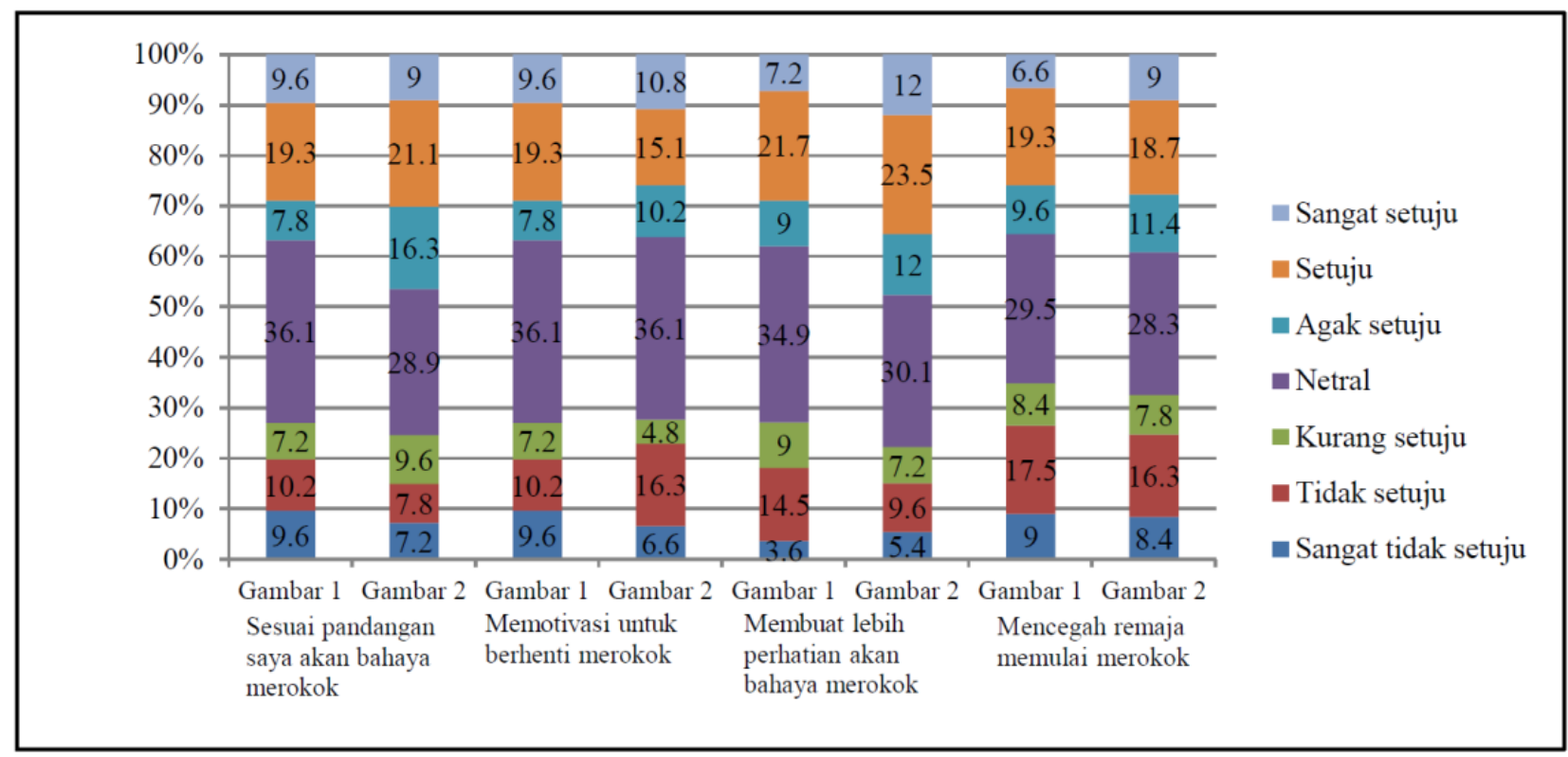


Figur 5. Distribusi Perokok Remaja Peserta Didik PKBM di Kota Depok berdasarkan Respon Penerima Pesan (Perilaku Batal Merokok) terkait paparan PKB di Bungkus Rokok Tahun 2015

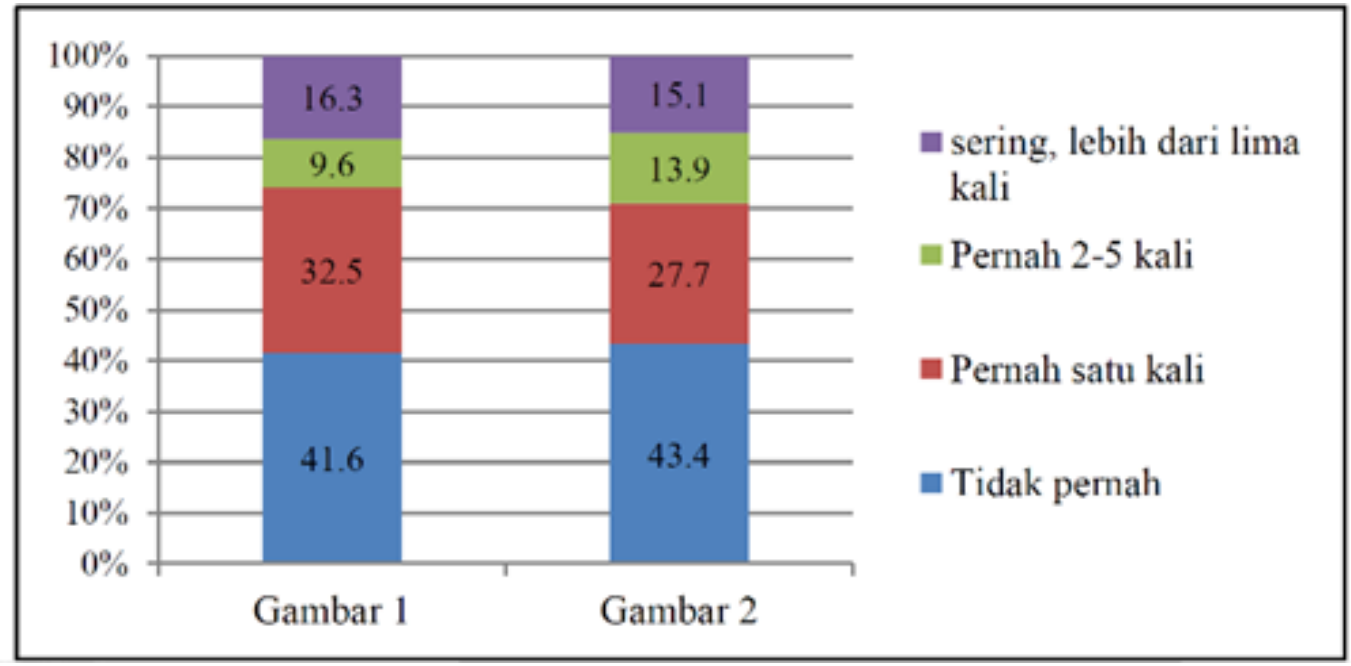

Figur 6. Distribusi Perokok Remaja Peserta Didik PKBM di Kota Depok berdasarkan Respon Penerimaan Pesan (Niat Berhenti Merokok) terkait paparan PKB di Bungkus Rokok Tahun 2015

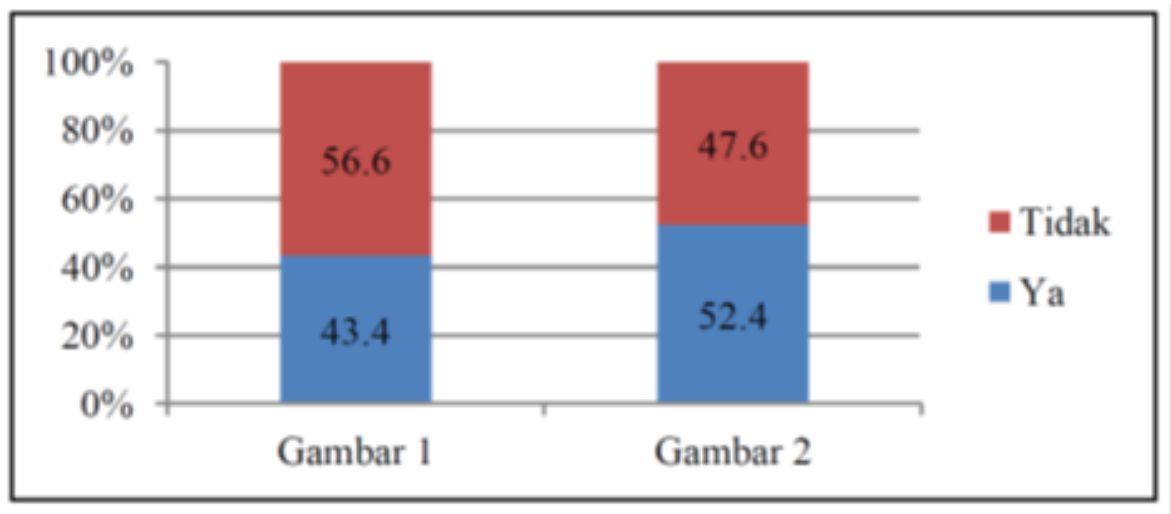

Dalam respon penolakan pesan, khususnya untuk variabel minimasi pesan dan reaktan, sebagian besar memberikan respon netral. Berdasarkan hasil penelitian, sebagian besar responden memberikan respon netral terhadap pernyataan bahwa pesan yang disampaikan dalam gambar tengkorak $(27,7 \%)$ dan gambar kanker mulut $(32,5 \%)$ terlalu mengada-ngada, kemudian sebagian besar responden memberikan respon netral terhadap pernyataan bahwa pesan yang disampaikan dalam gambar tengkorak $(31,9 \%)$ dan gambar kanker mulut $(33,1 \%)$ terlalu berlebihan. Untuk variabel reaktan, sebagian besar memberikan respon netral bahwa mereka merasa marah $(33,7 \%)$, merasa terganggu $(31,3 \%)$, merasa gusar $(36,1 \%)$, serta merasa dihakimi $(34,3 \%)$ ketika melihat peringatan kesehatan bergambar tengkorak. Kemudian, sebagian besar responden memberikan respon netral bahwa mereka merasa marah, gusar dan dihakimi (masingmasing $33,7 \%)$, serta terganggu (31,9\%). 
Figur 7. Distribusi Perokok Remaja Peserta Didik PKBM di Kota Depok berdasarkan Respon Penolakan Pesan (Minimasi Pesan dan Reaktan) terkait Paparan PKB di Bungkus Rokok Tahun 2015 ketika melihat peringatan kesehatan bergambar kanker mulut.

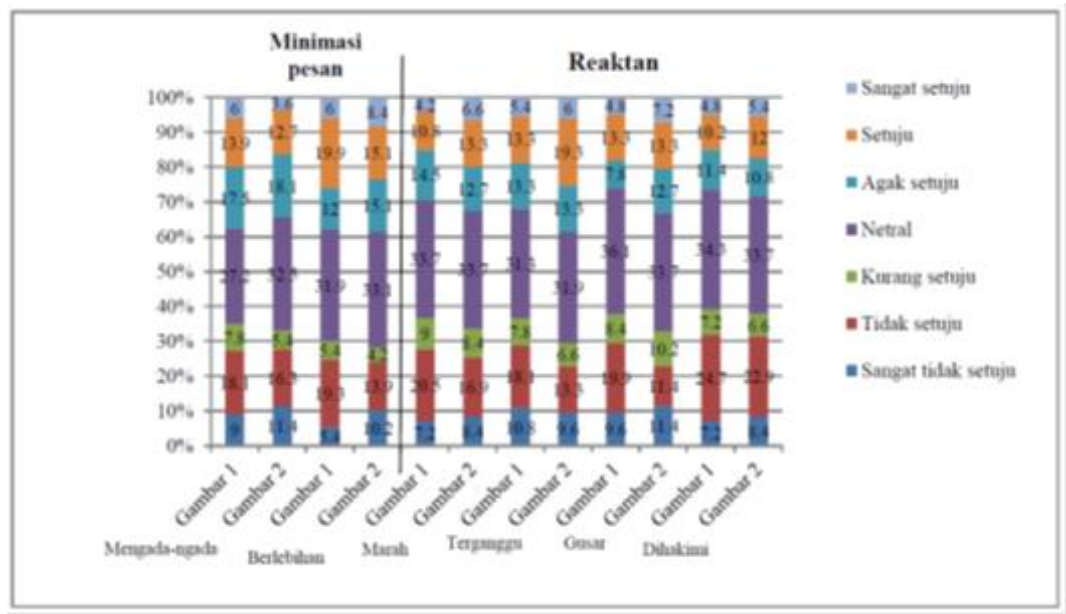

Untuk bentuk ketiga penolakan pesan yaitu menghindar, sebagian besar responden mengaku tidak pernah menghindari membeli rokok dengan kemasan bergambar tengkorak (37,3\%), merobek gambar tengkorak yang ada pada kemasan rokok yang ia beli $(36,1 \%)$, menutup gambar tengkorak dengan stiker atau korek $(47,0 \%)$, memindahkan rokok ke kotak tanpa peringatan kesehatan bergambar $(43,4 \%)$, mengabaikan $(25,9 \%)$ gambar tengkorak dan tetap merokok. Kemudian, sebagian besar responden mengaku tidak pernah menghindari membeli rokok dengan kemasan bergambar kanker mulut (35,5\%), merobek gambar kanker mulut yang ada pada kemasan rokok yang ia beli (42,8\%), menutup gambar kanker mulut dengan stiker atau korek $(44,6 \%)$, memindahkan rokok ke kotak tanpa peringatan kesehatan bergambar $(36,7 \%)$, mengabaikan $(27,7 \%)$ gambar kanker mulut dan tetap merokok.

Setelah memaparkan pola jawaban responden untuk setiap variabel EPPM, berikut akan dipaparkan hasil analisis bivariat setiap variabel untuk kedua gambar peringatan kesehatan (gambar tengkorak dan gambar kanker mulut). Berdasarkan tabel 3 terlihat bahwa terdapat perbedaan yang signifikan (pvalue $<0,05)$ antara rerata rasa takut terhadap $\mathrm{PKB}$ tengkorak $(\mathrm{M}=3,03)$ dengan rasa takut terhadap $\mathrm{PKB}$ kanker mulut $(\mathrm{M}=3,96)$.
Dalam hal persepsi ancaman (tabel 4), dari uji t dependen didapatkan nilai $t$ untuk keparahan sebesar 2,827 dan p-value sebesar 0,005. Karena p-value $<\alpha$ maka ada perbedaan mean keparahan kematian dan kanker mulut. Kemudian, dalam hal kerentanan, didapatkan nilai $\mathrm{t}$ sebesar 0,262 dan p-value sebesar 0,776 . Karena $\mathrm{p}$-value $>\alpha$, maka artinya tidak ada perbedaan yang signifikan mean kerentanan terhadap kematian dan kanker mulut akibat merokok. Namun, jika dilihat dari aspek persepsi ancaman, dengan nilai $\mathrm{t}$ sebesar 1,923 dan p-value sebesar 0,056 maka tidak ada perbedaan yang signifikan antara mean persepsi ancaman terhadap kematian akibat merokok $(M=3,95)$ dengan mean persepsi ancaman terhadap kanker mulut akibat merokok $(\mathrm{M}=4,12)$.

Kemudian dalam hal persepsi efikasi (tabel 5), berdasarkan uji $\mathrm{t}$ dependen, didapatkan nilai $\mathrm{t}$ untuk efikasi respon sebesar 3,276 dan $\mathrm{p}$-value $=0,001(\mathrm{p}$ value $<\alpha 0,05$ ), artinya ada perbedaan yang signifikan mean efikasi respon (mengurangi jumlah rokok yang dihisap dan berhenti merokok) untuk memperpanjang hidup dengan mencegah kanker mulut. 
Tabel 3. Gambaran Rerata Rasa Takut terhadap Peringatan Kesehatan Bergambar di Bungkus Rokok Tahun 2015

\begin{tabular}{lccccc}
\hline & \multicolumn{5}{c}{ Rasa Takut } \\
\hline Mean & $\begin{array}{l}\text { Standar } \\
\text { deviasi }\end{array}$ & $t$ & p-value \\
Gambar tengkorak & 3,03 & 1,612 & 8,497 & $<0,05$ \\
Gambar kanker mulut & 3,96 & 1,577 & & \\
\hline
\end{tabular}

Tabel 4. Gambaran Rerata Persepsi Ancaman terhadap Peringatan Kesehatan Bergambar di Bungkus Rokok Tahun 2015

\begin{tabular}{|c|c|c|c|c|c|c|c|c|c|c|c|c|}
\hline & \multicolumn{2}{|c|}{$\begin{array}{l}\text { Persepsi } \\
\text { ancaman }\end{array}$} & \multirow[t]{2}{*}{$\mathbf{t}$} & \multirow{2}{*}{$\begin{array}{c}\text { p- } \\
\text { value }\end{array}$} & \multicolumn{2}{|c|}{ Keparahan } & \multirow{2}{*}{$\mathbf{t}$} & \multirow{2}{*}{$\begin{array}{c}\text { p- } \\
\text { value }\end{array}$} & \multicolumn{2}{|c|}{ Kerentanan } & \multirow[t]{2}{*}{ t } & \multirow{2}{*}{$\begin{array}{c}\mathrm{p}- \\
\text { value }\end{array}$} \\
\hline & $\mathrm{M}$ & $\mathrm{SD}$ & & & $\mathrm{M}$ & SD & & & $\mathrm{M}$ & $\mathrm{SD}$ & & \\
\hline $\begin{array}{l}\text { Gambar } \\
\text { tengkorak }\end{array}$ & 3,95 & 1,302 & & & 4,00 & 1,318 & & & 3,89 & 1,500 & & \\
\hline $\begin{array}{c}\text { Gambar } \\
\text { kanker } \\
\text { mulut }\end{array}$ & 4,12 & 1,305 & 1,923 & 0,056 & 4,26 & 1,325 & 2,827 & 0,005 & 3,92 & 1,495 & 0,262 & 0,776 \\
\hline
\end{tabular}

Tabel 5. Gambaran Rerata Persepsi Efikasi terhadap Peringatan Kesehatan Bergambar di Bungkus Rokok Tahun 2015

\begin{tabular}{|c|c|c|c|c|c|c|c|c|c|c|c|c|}
\hline & \multicolumn{2}{|c|}{$\begin{array}{c}\text { Persepsi } \\
\text { efikasi }\end{array}$} & \multirow[t]{2}{*}{$\mathbf{T}$} & \multirow{2}{*}{$\begin{array}{c}\text { p- } \\
\text { value }\end{array}$} & \multicolumn{2}{|c|}{$\begin{array}{l}\text { Efikasi } \\
\text { respon }\end{array}$} & \multirow[t]{2}{*}{$t$} & \multirow{2}{*}{$\begin{array}{c}\text { p- } \\
\text { value }\end{array}$} & \multicolumn{2}{|c|}{ Efikasi diri } & \multirow[t]{2}{*}{ t } & \multirow{2}{*}{$\begin{array}{c}\mathrm{p}- \\
\text { value }\end{array}$} \\
\hline & $\mathrm{M}$ & SD & & & $\mathrm{M}$ & SD & & & $\mathrm{M}$ & SD & & \\
\hline $\begin{array}{l}\text { Gambar } \\
\text { tengkorak }\end{array}$ & 3,50 & 1,317 & & & 3,53 & 1,546 & & & 3,47 & 1,460 & & \\
\hline $\begin{array}{c}\text { Gambar } \\
\text { kanker } \\
\text { mulut }\end{array}$ & 3,76 & 1,371 & 2,817 & 0,005 & 3,92 & 1,513 & 3,276 & 0,001 & 3,59 & 1,505 & 1,225 & 0,223 \\
\hline
\end{tabular}

Kemudian, nilai t untuk efiksi diri sebesar 1,225 dengan niali $\mathrm{p}$ sebesar 0,223 ( $\mathrm{p}$-value > 0,05), artinya tidak ada perbedaan yang signifikan antara mean efikasi diri untuk memperpanjang usia hidup dengan efikasi diri untuk untuk mencegah kanker mulut. Jika dilihat dari aspek persepsi efikasi, dengan nilai $\mathrm{t}$ sebesar 2,817 dan p-value sebesar 0,005 maka ditemukan perbedaan yang signifikan antara mean persepsi efikasi terhadap kematian $(\mathrm{M}=3,50)$ dengan mean persepsi efikasi terhadap kanker mulut akibat merokok $(\mathrm{M}=3,76)$.

Berdasarkan tabel 6, didapatkan mean untuk sikap terhadap PKB tengkorak sebesar 4,11 dan mean untuk sikap terhadap PKB kanker mulut sebesar 4,29. Hasil uji t didapatkan hasil nilai t sebesar 1,832 dan $\mathrm{p}=0,69$ ( $p>0,05)$ sehingga dapat disimpulkan bahwa tidak ada perbedaan yang signifikan antara mean sikap terhadap PKB tengkorak dengan mean sikap terhadap PKB kanker mulut. 
Tabel 6. Gambaran Mean (Sikap dan Perilaku) dan Frekuensi (Niat) terhadap Peringatan Peringatan Kesehatan Bergambar di Bungkus Rokok Tahun 2015

\begin{tabular}{|c|c|c|c|c|c|c|c|c|c|c|c|c|}
\hline & \multicolumn{2}{|c|}{$\begin{array}{c}\text { Sikap } \\
\text { terhadap } \\
\text { PKB }\end{array}$} & \multirow{2}{*}{$t$} & \multirow{2}{*}{$\begin{array}{c}\text { p- } \\
\text { value }\end{array}$} & \multicolumn{2}{|c|}{$\begin{array}{c}\text { Perilaku } \\
\text { batal } \\
\text { merokok }\end{array}$} & \multirow{2}{*}{$t$} & \multirow{2}{*}{$\begin{array}{c}\text { p- } \\
\text { value }\end{array}$} & \multicolumn{2}{|c|}{$\begin{array}{l}\text { Niat berhenti } \\
\text { merokok }\end{array}$} & \multirow{2}{*}{ df } & \multirow{2}{*}{$\begin{array}{c}\mathrm{p}- \\
\text { value }\end{array}$} \\
\hline & M & SD & & & M & SD & & & $\begin{array}{l}\text { Ya } \\
(\%)\end{array}$ & Tidak (\%) & & \\
\hline $\begin{array}{c}\text { Gambar } \\
\text { tengkorak }\end{array}$ & 4,11 & 1,304 & & & 2,01 & 1,082 & & & 43,4 & 56,6 & & \\
\hline $\begin{array}{c}\text { Gambar } \\
\text { kanker } \\
\text { mulut }\end{array}$ & 4,29 & 1,339 & 1,832 & 0,69 & 2,01 & 1,087 & 0,000 & 1,000 & 52,4 & 47,6 & 1 & $<0,05$ \\
\hline
\end{tabular}

Untuk perilaku batal merokok, baik gambar tengkorak maupun kanker mulut memiliki mean masing-masing sebesar 2,01. Hasil uji t menunjukan nilai $\mathrm{t}=0,000$ dan $\mathrm{p}$-value $=1,000(\mathrm{p}$-value $>0,05)$, artinya tidak ada perbedaan yang signifikan antara mean perilaku batal merokok akibat melihat gambar tengkorak dengan mean perilaku batal merokok akibat melihat gambar kanker mulut. Untuk niat berhenti merokok, berdasarkan uji statistik, didapatkan derajat kebebasan (df) untuk variabel niat sebesar 1 dengan pvalue $<0,05$, sehingga secara statistik terbukti bahwa terdapat perbedaan yang signifikan antara frekuensi niat berhenti merokok ketika melihat gambar tengkorak dengan frekuensi niat berhenti merokok ketika melihat gambar kanker mulut di bungkus rokok.

Untuk respon penolakan pesan (minimasi pesan, reaktan, menghindar), tidak ditemukan perbedaan yang signifikan antara kedua gambar PKB (tengkorak dan kanker mulut). Berdasarkan analisis statistik didapatkan mean untuk minimasi pesan terhadap PKB tengkorak sebesar 4,01 dan terhadap PKB kanker mulut mean sebesar 3,95. Hasil uji beda dua mean menunjukan nilai t sebesar $-0,536$ dan $\mathrm{p}$-value $=0,592$ (p-value> 0,05), artinya tidak ada perbedaan yang signifikan mean minimasi pesan antara kedua gambar peringatan kesehatan tersebut (gambar tengkorak dan gambar kanker mulut).

Hasil analisis menunjukkan rerata untuk penolakan terhadap pesan bergambar tengkorak sebesar 3,74 $(\mathrm{SD}=1,38)$. Penolakan terhadap peringatan bergambar kanker mulut memiliki rerata sebesar 3,92 ( $\mathrm{SD}=1,43)$.
Hasil uji beda menunjukan nilai t sebesar 1,809 (pvalue $=0,07$ ). Karena $\mathrm{p}$-value lebih besar dari nilai $\alpha$, artinya tidak ada perbedaan yang signifikan mean reaktansi antara PKB tengkorak maupun PKB kanker mulut. Kemudian, berdasarkan tabel 7, dalam hal menghindar tidak terdapat perbedaan yang signifikan untuk semua bentuk menghindar (menghindar, merobek, menutup, memindahkan ke kotak tanpa PKB, mengabaikan) antara PKB tengkorak maupun PKB kanker mulut.

\section{DISKUSI}

Dalam penelitian ini, hampir seluruh responden berjenis kelamin laki-laki $(91,6 \%)$ dan sisanya perempuan $(8,4 \%)$ yang sejalan dengan proporsi perokok remaja pria di tingkat nasional dan global yang lebih banyak daripada perokok remaja wanita.,5 Begitu pula dengan rata-rata usia pertama kali merokok responden dalam penelitian ini (13 tahun) yang sejalan dengan data nasional bahwa rata-rata usia mulai merokok setiap hari secara nasional adalah 17,6 tahun namun $12,3 \%$ diantaranya mulai merokok sebelum usia 15 tahun. ${ }^{5}$ Kemudian, hasil penelitian menunjukkan sebagian besar responden $(89,2 \%)$ mengaku merokok lebih dari satu kali dalam sebulan terakhir, dan sebagian besar responden $(68,1 \%)$ memiliki tingkat adiksi rendah, hal ini juga sejalan dengan data di tingkat nasional. ${ }^{5}$ 
Tabel 7. Gambaran Mean Respon Penolakan Pesan terhadap Peringatan Kesehatan Bergambar di Bungkus Rokok Tahun 2015

\begin{tabular}{|c|c|c|c|c|c|c|c|c|c|c|c|c|}
\hline & \multicolumn{2}{|c|}{$\begin{array}{c}\text { Minimasi } \\
\text { pesan }\end{array}$} & \multirow[t]{2}{*}{$t$} & \multirow{2}{*}{$\begin{array}{c}\text { p- } \\
\text { value }\end{array}$} & \multicolumn{2}{|c|}{ Reaktan } & \multirow[t]{2}{*}{$t$} & \multirow{2}{*}{$\begin{array}{c}\mathrm{p}- \\
\text { value }\end{array}$} & \multicolumn{2}{|c|}{$\begin{array}{c}\text { Menghindari } \\
\text { PKB }\end{array}$} & \multirow[t]{2}{*}{$t$} & \multirow[t]{2}{*}{$\begin{array}{c}\mathrm{p}- \\
\text { value }\end{array}$} \\
\hline & $\mathrm{M}$ & $\mathrm{SD}$ & & & M & SD & & & $\mathrm{M}$ & SD & & \\
\hline $\begin{array}{l}\text { Gambar } \\
\text { tengkorak }\end{array}$ & 4,01 & 1,475 & & & 3,74 & 1,378 & & & 2,79 & 1,737 & & \\
\hline $\begin{array}{c}\text { Gambar } \\
\text { kanker } \\
\text { mulut }\end{array}$ & 3,95 & 1,520 & 0,536 & 0,592 & 3,92 & 1,427 & 1,809 & 0,072 & 2,87 & 1,811 & 0,523 & 0,602 \\
\hline
\end{tabular}

Tabel 7. (sambungan)

\begin{tabular}{|c|c|c|c|c|c|c|c|c|}
\hline & \multicolumn{2}{|c|}{$\begin{array}{c}\text { Merobek } \\
\text { PKB }\end{array}$} & \multirow[t]{2}{*}{$t$} & \multirow{2}{*}{$\begin{array}{c}\mathrm{p}- \\
\text { value }\end{array}$} & \multicolumn{2}{|c|}{$\begin{array}{c}\text { Menutup } \\
\text { PKB }\end{array}$} & \multirow[t]{2}{*}{$t$} & \multirow{2}{*}{$\begin{array}{c}\mathrm{p}- \\
\text { value }\end{array}$} \\
\hline & $\mathrm{M}$ & SD & & & $\mathrm{M}$ & SD & & \\
\hline $\begin{array}{c}\text { Gambar } \\
\text { tengkorak }\end{array}$ & 2,92 & 1,817 & & & 2,56 & 1,760 & & \\
\hline $\begin{array}{c}\text { Gambar } \\
\text { kanker } \\
\text { mulut }\end{array}$ & 2,94 & 1,877 & 0,212 & 0,832 & 2,75 & 1,886 & 1,654 & 0,100 \\
\hline
\end{tabular}

Tabel 7. (sambungan)

\begin{tabular}{|c|c|c|c|c|c|c|c|c|}
\hline \multirow[b]{3}{*}{$\begin{array}{c}\text { Gambar } \\
\text { tengkorak }\end{array}$} & \multicolumn{2}{|c|}{$\begin{array}{c}\text { Memindahkan } \\
\text { ke kotak tanpa } \\
\text { PKB }\end{array}$} & \multirow[t]{2}{*}{$t$} & \multirow[t]{2}{*}{ p-value } & \multicolumn{2}{|c|}{ Mengabaikan PKB } & \multirow[t]{2}{*}{$t$} & \multirow[t]{2}{*}{$\begin{array}{c}\mathrm{p}- \\
\text { value }\end{array}$} \\
\hline & $\mathrm{M}$ & $\mathrm{SD}$ & & & $\mathrm{M}$ & SD & & \\
\hline & 2,55 & 1,690 & & & 3,23 & 1,729 & & \\
\hline $\begin{array}{c}\text { Gambar } \\
\text { kanker } \\
\text { mulut }\end{array}$ & 2,65 & 1,761 & 0,875 & 0,383 & 3,13 & 1,787 & $-0,645$ & 0,518 \\
\hline
\end{tabular}

Hasil penelitian menunjukkan bahwa terdapat perbedaan yang gambar kanker secara signifikan (pvalue $<0,05)$ lebih menakutkan $(M=3,96)$ daripada gambar tengkorak $(M=3,03)$, yang sejalan dengan hasil penelitian sebelumnya. ${ }^{10}$ Dalam hal persepsi ancaman, secara signifikan $(\mathrm{p}$-value $=0,005)$ responden merasa bahwa kanker mulut $(M=4,92)$ lebih parah daripada kematian akibat merokok $(M=4,00)$. Hal ini sejalan dengan penelitian sebelumnya. ${ }^{11}$ Namun, tidak ditemukan perbedaan signifikan ( $\mathrm{p}$-value $=0,776)$ antara rerata persepsi kerentanan terhadap kematian akibat merokok $(M=3,89)$ dengan rerata kerentanan terhadap kanker mulut akibat merokok $(M=3,92)$, hal ini sejalan dengan hasil penelitian sebelumnya. ${ }^{12}$ Jika dilihat dari aspek persepsi ancaman, tidak ada perbedaan yang signifikan $(\mathrm{p}=0,056)$ antara rerata persepsi ancaman terhadap kematian akibat merokok $(M=3,95)$ dengan rerata persepsi ancaman terhadap kanker mulut akibat merokok $(M=4,12)$, yang mana sejalan dengan teori kesan menakutkan. ${ }^{13}$

Kemudian, dalam hal efikasi untuk mengurangi jumlah rokok dan berhenti merokok, secara signifikan (p-value $=0,001)$ responden meyakini bahwa mengurangi jumlah rokok yang dihisap dan berhenti merokok lebih efektif mencegah kanker mulut $(M=3,92)$ daripada memperpanjang usia hidup $(M=3,53)$, hal ini sejalan dengan hasil penelitian terdahulu. ${ }^{14}$ Berbeda halnya dengan persepsi efikasi respon, tidak ditemukan adanya perbedaan yang signifikan $(\mathrm{p}=0,223)$ antara persepsi efikasi diri berkaitan dengan gambar tengkorak $(M=3,47)$ dengan persepsi efikasi diri berkaitan dengan gambar kanker 
mulut $(M=3,59)$. Responden merasa cukup yakin dapat mengurangi jumlah rokok yang dihisap dan berhenti merokok untuk memperpanjang usia hidup atau mencegah kanker mulut. Artinya, responden masih belum benar-benar yakin akan kemampuan dirinya. ${ }^{14,15}$ Jika dilihat dari persepsi efikasi (gabungan dari efikasi respon dan efiksasi diri), ternyata secara signifikan $(\mathrm{p}=0,005)$ responden merasa yakin mengurangi jumlah rokok yang dihisap dan berhenti merokok lebih efektif mencegah kanker mulut $(M=3,76)$ daripada untuk memperpanjang usia hidup $(M=3,50)$, dan mereka pun lebih yakin dapat melakukan kedua hal tersebut, sebagaimana pernah juga dinyatakan dalam peneltian sebelumnya. ${ }^{16}$

Respon penerimaan pesan, untuk variabel sikap menunjukkan responden cenderung netral $(M=4,11$ dan $M=4,29)$ terhadap pesan yang disampaikan dalam PKB tengkorak maupun kanker mulut ( $\mathrm{p}$-value $=0,69)$, yang mana sejalan dengan penelitian sebelumnya. ${ }^{8,13,17}$ Untuk perilaku batal merokok, peringatan kesehatan bergambar baik gambar tengkorak $(M=2,01)$ maupun kanker mulut $(M=2,01)$ hanya pernah sekali membuat seseorang batal merokok (p-value $=1,000$ ), hal ini sejalan dengan hasil penelitian terdahulu. ${ }^{8,17}$ Dalam hal niat berhenti merokok, penelitian menemukan bahwa secara signifikan (p-value $<0,05)$ responden yang melihat PKB kanker mulut lebih banyak yang niat berhenti merokok dalam enam bulan daripada ketika melihat PKB tengkorak, yang mana sejalan dengan hasil penelitian sebelumnya. ${ }^{18}$

Berdasarkan respon penolakan oleh pasien, peneliti tidak menemukan adanya perbedaan yang signifikan $(\mathrm{p}=0,592)$. Responden rata-rata memilih untuk netral terhadap pesan yang disampaikan dalam PKB tengkorak $(M=3,95)$ maupun PKB kanker mulut $(M=4,01)$. Temuan ini sejalan dengan hasil penelitian terdahulu. ${ }^{19}$ Dalam hal penolakan, hasil penelitian menunjukan bahwa tidak ada perbedaan yang signifikan (p-value $=0,072$ ), di mana responden merasa biasa saja terhadap PKB bergambar tengkorak $(M=3,74)$ maupun PKB bergambar kanker mulut $(M=3,92)$. Hal ini sejalan dengan hasil penelitian sebelumnya. $^{20}$ Dalam hal menghindar, penelitian menunjukkan untuk setiap bentuk menghindar tidak ditemukan perbedaan yang signifikan antara gambar tengkorak dan gambar kanker mulut. Setiap bentuk menghindar memiliki rerata berkisar antara skala 2-3 (pernah sekali - beberapa kali). Artinya, baik gambar tengkorak maupun kanker mulut memang dihindari oleh para perokok, yang mana hasil serupa juga ditemukan dari studi peringatan kesehatan terdahulu. ${ }^{15}$

\section{Kesimpulan}

1. Secara signifikan, gambar kanker mulut lebih menakutkan daripada gambar tengkorak.

2. PKB tengkorak maupun kanker mulut kurang mampu membuat responden merasa terancam akan risiko kesehatan yang digambarkan dalam peringatan kesehatan tersebut.

3. Secara signifikan, responden merasa bahwa mengurangi jumlah rokok yang dihisap dan berhenti merokok lebih efektif dalam mencegah kanker mulut daripada menambah usia hidup, serta responden pun yakin mampu melakukan kedua hal tersebut.

4. Penelitian tidak menemukan perbedaan gambaran respon penerimaan pesan dalam sikap dan perilaku batal merokok. Berbeda halnya dengan niat, ternyata responden yang melihat gambar kanker mulut lebih banyak yang berniat berhenti merokok daripada ketika melihat gambar tengkorak.

5. Dalam hal respon penolakan pesan, baik minimasi pesan, reaktan, responden cenderung memilih untuk netral terhadap pesan dalam PKB tengkorak maupun kanker mulut. Namun, ternyata responden pernah beberapa kali menghindari PKB tengkorak maupun kanker mulut.

\section{Saran}

1. Untuk peringatan kesehatan bergambar di Indonesia, perlu adanya tambahan komponen efikasi ("Dengan berhenti merokok, Anda akan terhindar dari kanker mulut") dalam peringatan kesehatan bergambar agar para perokok tahu bagaimana cara mencegah efek kesehatan akibat merokok dan termotivasi untuk berhenti merokok.

2. Gambar yang menunjukkan penyakit akibat merokok dalam peringatan kesehatan bergambar perlu dipertahankan di Indonesia karena mampu membuat seseorang yang melihatnya merasa takut akan efek kesehatan akibat merokok yang digambarkan oleh gambar tersebut.

3. Peneliti lain dapat meneliti PKB pada putaran kedua berdasarkan EPPM dengan menggunakan desain studi yang dapat menjelaskan hubungan sebab akibat. 


\section{Daftar Referensi}

1. World Health Organization. The top 10 causes of death.; 2014. Available at: http://www.who.int/mediacentre/factsheets/fs 310/en/.

2. World Health Organization. Gender, Women, and the Tobacco Epidemic.; 2010. doi:10.1080/13552074.2011.592653.

3. Eriksen M, Mackay J, Schluger N, Islami F, Drope J. The Tobacco Atlas. 5th ed. Atlanta, Georgia: American Cancer Society; 2015. Available at: http://www.tobaccoatlas.org.

4. Clayton RR, Caudill CA, Segress MJH. Tobacco use and adolescent health. In: DiClemente RJ, Santelli JS, Crosby RA, eds. Adolescent health: understanding and preventing risk behaviors. San Francisco: Jossey-Bass Publishers; 2009:131-146. Available at: https://www.cabdirect.org/cabdirect/abstract/2 0113025223. Accessed March 12, 2018.

5. National Institute for Health Research \& Development. Riset Kesehatan Dasar (National Health Survey). Jakarta; 2013. doi:10.1007/s13398-014-0173-7.2.

6. Pusat Penelitian Kesehatan, Badan Narkotika Nasional. Survey Penyalahgunaan dan Peredaran Gelap Narkoba pada Kalangan Pelajar/ Mahasiswa Di Kota Depok. Depok; 2012.

7. Ganley BJ, Rosario DI. The smoking attitudes, knowledge, intent, and behaviors of adolescents and young adults: Implications for nursing practice. J Nurs Educ Pract. 2013;3(1):40. doi:10.5430/jnep.v3n1p40.

8. Witte K. Putting the fear back into fear appeals: The extended parallel process model. Commun Monogr. 1992;59(4):329-349. doi:10.1080/03637759209376276.

9. Notoatmodjo S. Metodologi penelitian kesehatan. Jakarta: Rineka Cipta; 2010.

10. Dewi NC, Damayanti R. Perbedaan Persepsi Gambar Peringatan Bahaya Merokok antara Masyarakat Jakarta dan Cirebon. Kesmas Natl Public Heal J. 2008;3(2):76. doi:10.21109/kesmas.v3i2.233.

11. Hammond D, Reid JL, Driezen P, Boudreau C. Pictorial health warnings on cigarette packs in the United States: an experimental evaluation of the proposed FDA warnings. Nicotine Tob Res. 2012;15(1):93-102. doi:10.1093/ntr/nts094.

12. Hammond D, Thrasher JF, Reid JL, Driezen P, Boudreau C, Santillán EA. Perceived effectiveness of pictorial health warnings among Mexican youth and adults: a population-level intervention with potential to reduce tobacco-related inequities. Cancer Causes Control. 2012;23:57-67. doi:10.1007/s10552-012-9902-4.

13. Witte K. Fear control and danger control: A test of the extended parallel process model (EPPM). Commun Monogr. 1994;61(2):113134. doi:10.1080/03637759409376328.

14. Rahmawati AAD. Persepsi remaja terhadap kesan menakutkan pada peringatan kesehatan bergambar di bungkus rokok ditinjau dari Extended Parallel Process Model. Skripsi. 2015;1(1).

15. TNS Qual. Eurobarometer qualitative study on tobacco packaging health warning labels.; 2012

16. Hammond D. Health warning messages on tobacco products: a review. Tob Control. 2011;20(5):327-37. doi:10.1136/tc.2010.037630.

17. Popova L. The extended parallel process model: illuminating the gaps in research. Heal Educ Behav. 2012;39(4):455-73. doi:10.1177/1090198111418108.

18. Kees J, Burton S, Andrews JC, Kozup J. Understanding how graphic pictorial warnings work on cigarette packaging. J Public Policy Mark. 2010;29(2):265-276. doi:10.1016/j.tree.2009.02.010.

19. Thrasher JF, Arillo-Santillán E, Villalobos V, et al. Can pictorial warning labels on cigarette packages address smoking-related health disparities? Field experiments in Mexico to assess pictorial warning label content. Cancer Causes Control. 2012;23 Suppl 1:69-80. doi:10.1007/s10552-012-9899-8.

20. Rains SA, Turner MM. Psychological Reactance and Persuasive Health Communication: A Test and Extension of the Intertwined Model. Hum Commun Res. 2007;33(2):241-269. doi:10.1111/j.14682958.2007.00298.x 